\title{
Internal consistency and confirmatory validity of the parenting practices inventory in a Mexican population sample
}

\author{
Alejandra Soriano Rodríguez, 'Jorge Caraveo Anduaga, 'Jorge Luis López Jiménez, ${ }^{1}$ Silvia Carreño-García, \\ Francisco Juárez García'
}

Dirección de Investigaciones Epidemiológicas y Psicosociales. Instituto Nacional de Psiquiatría Ramón de la Fuente Muñiz. Ciudad de México, México.

\section{Correspondence:}

Jorge Javier Caraveo Anduaga

Dirección de Investigaciones Epidemiológicas y Psicosociales, Instituto Nacional de Psiquiatría Ramón de la Fuente Muñiz.

Calzada México-Xochimilco 101. Col. San Lorenzo Huipulco, Tlalpan CP 014370 . Ciudad de México, México.

Phone: 554160 - 5169

Email: caraveoj@imp.edu.mx

Received: 21 August 2018

Accepted: 3 June 2019

Citation:

Soriano Rodríguez, A., Caraveo Anduaga, J., López Jiménez, J. L., Carreño-García, S., \& Juárez García, F. (2019). Internal consistency and confirmatory validity of the parenting practices inventory in a mexican population sample. Salud Mental, 42(3), 137-143.

DOI: $10.17711 /$ SM.0185-3325.2019.018

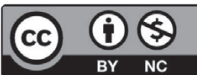

\begin{abstract}
Introduction. Parenting practices refer to specific behaviours used by parents and caretakers of children to guide childhood development and socialization goals. These practices are associated with children's health, psychological, and physical development. Objective. To determine the psychometric properties of the Parenting Practices Inventory (PPI) among a group of child caregivers in Mexico City. Method. The PPI was applied to 443 caregivers of children and adolescents, who attended a general health care centre in Mexico City. For the psychometric evaluation of the instrument, the full distribution and discrimination of the items was analysed first. Then, the validity of the construct was tested through an exploratory factor analysis and a confirmatory analysis with structural equation modelling. Results. The internal consistency of the PPI showed $\alpha=.867$ and $41.25 \%$ of variance explained for all four dimensions of interest. The confirmatory factor analysis showed that the model had goodness of fit. It included twenty-four items with adequate consistency and validity indices. Discussion and conclusion. The PPI is therefore a potentially useful psychometric measure for evaluating parenting practices among this type of population and could have major implications for the development of interventions and preventive programmes. It provides scientific bases for diagnostic decision-making and primary health care from the moment of initial contact to specialized medical care.
\end{abstract}

Keywords: Parenting, Parenting Practices Inventory (PPI), psychometrics, reliability, validity, primary care.

\section{RESUMEN}

Introducción. Las prácticas de crianza se refieren a comportamientos específicos utilizados por los padres y cuidadores de niños para guiar su desarrollo y metas de socialización infantil. Estas prácticas están asociadas con la salud, el desarrollo psicológico y físico de los niños. Objetivo. Determinar las propiedades psicométricas del Inventario de Prácticas de Crianza (IPC) entre un grupo de cuidadores de niños en la Ciudad de México. Método. El IPC se aplicó a 443 cuidadores de niños y adolescentes, que asistieron a consulta médica general en un Centro de salud en la Ciudad de México. Para la evaluación psicométrica del instrumento se analizó la distribución total y la discriminación de los reactivos. La validez de constructo se probó a través de análisis factorial exploratorio y análisis confirmatorio con modelos de ecuaciones estructurales. Resultados. EI IPC mostró $\alpha=.867$ y $41.25 \%$ de la varianza explicada para las cuatro dimensiones de interés. El análisis factorial confirmatorio mostró que el modelo tuvo buena bondad de ajuste. Incluyó veinticuatro ítems con una consistencia e índices de validez adecuados. Discusión y conclusión. El IPC es una medida psicométrica potencialmente útil para evaluar las prácticas de crianza en esta población y podría tener implicaciones importantes para el desarrollo de intervenciones y programas preventivos. Esto brinda bases científicas para la toma de decisiones en la atención primaria de la salud desde el momento del contacto inicial hasta la atención médica especializada en caso de ser requerida.

Palabras clave: Parentalidad, Inventario de Prácticas de Crianza (IPC), psicometría, validez, confiabilidad, atención primaria. 


\section{INTRODUCTION}

Parental practices (PP), refer to specific behaviours used by parents and caretakers of children to guide childhood development and socialization goals (Myers, 1993; SolísCámara \& Díaz, 2007). These practices are associated with the children's health, nutrition, and psychological and physical development, and their ability to learn everyday life skills that enable them to develop socially and create a safe environment (Darling \& Steinberg, 1993; Forgatch \& Patterson, 2010; Forgatch, Patterson, Degarmo, \& Beldavs, 2009; Pichardo, Justicia, \& Fernández, 2009; Repetti, Taylor, \& Seeman, 2002).

Parenting practices have a direct impact on children's behaviour (Solís-Cámara et al., 2007) as care patterns may act as risk factors when they foster behavioural issues or child psychopathology (Myers, 1993; Vera \& Moon, 2013; Cuervo, 2010; Denham et al., 2000; Hill, 2002; Séguin \& Pilon, 2013; Shaw, Gilliom, Ingoldsby, \& Nagin, 2003), and may also be protective when they are positive, encouraging the development of skills and self-confidence in the child (Bauermeister, Cumba, Martínez, \& Puente, 2008; Ramírez, 2007).

As part of the Epidemiological Surveillance of Children and Adolescents' Mental Health Project (Caraveo, 2016), it was considered that PP should be evaluated. Thus, the Parental Practices Inventory (PPI), was chosen on the basis of what was both ideal and practical. The PPI is a 37-item self-report questionnaire for parents developed in Puerto Rico using items from the Parent Practices Scales (Strayhorn \& Weidman, 1988) and the Parenting Scale (Arnold, O'Leary, Wolff, \& Acker, 1993), as well as additional items based on the clinical experience of the authors. It was basically created to evaluate positive and negative practices across four areas: parental surveillance, supervision, participation, and discipline used (Bauermeister et al., 2008; Salas, 2001).

The aim of this study is to determine the psychometric characteristics, reliability, and confirmatory construct validity of the PPI for identifying the parenting methods used by caregivers of children and adolescents who attend healthcare facilities in Mexico City.

\section{METHOD}

\section{Study design and participants}

In a cross-sectional design, a secondary analysis was conducted in a sample of 443 caregivers of children and adolescents (ages 5-19) (Table 1), who participated in a larger study of patients who attended the general healthcare facilities of the Health Centre in order to establish the basic requirements for children's mental health surveillance (Caraveo et al., 2011).

\section{Procedure}

Individual face-to-face interviews were conducted with the adults responsible for the child's everyday care and lived with them on a daily basis. Interviewers were previously trained psychologists with experience working in the community.

\section{Instruments}

The original 37-item PPI was used, answered on a Likert type scale with four options: $0=$ never or almost never, $1=$ sometimes, 2 = frequently, and 3 = very frequently. Reliability reported by the authors showed an Cronbach's alpha consistency of .85 and a bidimensional positive and negative parenting internal structure (Bauermeister et al., 2005). Negative parenting includes fourteen items referring to inconsistency (e.g., not agreeing), withdrawal of love (e.g., not saying that they love the child), and coercion-based behavioural control (e.g., punishment, insults, and yelling). A second positive parenting component includes 23 items referring to positive parenting practices, including approval strategies (praise), acceptance (commendation, encouragement), communication (reasoning, explaining), motivation (rewards, loss of privileges, etc.), synchronization (paying attention, being sensitive, and responsive to the child), and affection (physical and emotional contact).

The items regarding positive practices were recorded so that the entire scale had the same significance, higher scores indicating a greater presence of inadequate PPs.

\section{Statistical analysis}

Descriptive statistics were obtained for caregivers' socio-demographic characteristics. After reviewing that data showed a normal distribution, the internal consistency for the whole test and subscales was estimated using the Cronbach's alpha statistic. The PPI construct validity was analysed with exploratory and confirmatory analyses using the maximum likelihood estimation method (MLE). An exploratory factorial analysis of the main components and varimax rotation with a KMO normalization adjustment (Kerlinger, 1986; Kerlinger \& Lee, 2002) was done. The criteria for including an item was that it should have a load higher than or equal to 0.40 and that it was not included in any other factor (Lloret et al., 2014). The SPSS for Windows (version 21) statistics package was used (IBM, 2012).

The information obtained from the exploratory analysis was subjected to a factorial confirmatory process with structural equation modelling in Bentler and Wu's Structural Equations Programme (Bentler \& Wu, 2005). This methodology is used to correct possible errors due to no-normal data distribution. The following goodness-of-fit indicators were used: 1 . chi-square divided by degrees of freedom 
Table 1

Caregiver characteristics $(N=443)$

\begin{tabular}{|c|c|c|}
\hline & $n$ & $\%$ * \\
\hline \multicolumn{3}{|l|}{$\operatorname{Sex}(n=423)$} \\
\hline Male & 20 & 4.5 \\
\hline Female & 423 & 95.5 \\
\hline \multicolumn{3}{|c|}{ Respondent's age $(n=414)$} \\
\hline 30 or over & 106 & 25.6 \\
\hline $31-40$ & 221 & 53.4 \\
\hline 41 or over & 87 & 21.0 \\
\hline \multicolumn{3}{|c|}{$\bar{X}=35.7, S D=8.7$, Min. $=15$, Max. $=74$} \\
\hline \multicolumn{3}{|c|}{ Type of caregiver $(n=443)$} \\
\hline Mother & 387 & 87.4 \\
\hline Father & 15 & 3.4 \\
\hline Grandmother & 17 & 3.8 \\
\hline Aunt & 6 & 1.4 \\
\hline Brother/sister & 8 & 1.8 \\
\hline Guardian & 4 & .9 \\
\hline Step-mother & 3 & .7 \\
\hline Self-report & 3 & .7 \\
\hline \multicolumn{3}{|c|}{ Are you a child caregiver? $(n=443)$} \\
\hline Yes & 435 & 97.6 \\
\hline No & 8 & 2.4 \\
\hline \multicolumn{3}{|c|}{ Professional occupation ( $n=412)$} \\
\hline Professional & 12 & 2.9 \\
\hline Business person & 19 & 4.6 \\
\hline Service provider & 113 & 27.4 \\
\hline Homemaker & 260 & 63.1 \\
\hline Student & 6 & 1.5 \\
\hline Unemployed & 2 & .5 \\
\hline \multicolumn{3}{|l|}{ Civil status $(n=414)$} \\
\hline Single & 61 & 14.7 \\
\hline Married & 227 & 54.8 \\
\hline Divorced & 6 & 1.4 \\
\hline Widowed & 13 & 3.1 \\
\hline Separated & 24 & 5.8 \\
\hline Common-law & 83 & 20.0 \\
\hline
\end{tabular}

*Percentages obtained from valid number of participants.

(quotients $<2$ indicated good fit), 2. the Bentler comparative adjustment index (robust comparative fit index), and 3. the root mean square error of approximation (RMSEA). A good fit was acknowledged if the RFCI was equal to or greater than .95 and the RMSEA value was $\leq .05$.

Lastly, a comparative analysis (Student's $t$-test) of parenting practices using the characteristics of the children and their caregivers was performed.

\section{Ethical considerations}

The study was previously approved by the Ethics Committee and the Research Commission of the Instituto Nacional de Psiquiatría. The PPI was applied with the participants'
Table 2

Characteristics of children and adolescents $(N=443)$

\begin{tabular}{lrr}
\hline & $n$ & $\%^{*}$ \\
\hline Sex $(n=443)$ & 177 & 40.0 \\
Male & 266 & 60.0 \\
Female & & \\
Age $(n=443)$ & 132 & 29.8 \\
$5-8$ & 155 & 35.1 \\
$9-12$ & 156 & 35.1 \\
13 or older & & \\
$\bar{X}=11.09$, SD $=3.46$, Min. $=5$, Max. $=19$ & \\
Schooling $(n=432)$ & & \\
Preschool & 11 & 2.6 \\
Elementary school & 241 & 57.1 \\
Middle school & 118 & 28.0 \\
High School & 52 & 12.3 \\
Does not attend school & 10 & 2.3 \\
Child's birth order $(n=443)$ & & \\
First born & 207 & 46.7 \\
Second born & 128 & 28.9 \\
Third born & 74 & 16.7 \\
Fourth born & 19 & 4.3 \\
Fifth born & 11 & 2.5 \\
Sixth born & 3 & .7 \\
Seventh born & 1 & .2 \\
\hline
\end{tabular}

*Percentages obtained from valid number of participants.

informed consent, and anonymity, confidentiality, and data protection measures were guaranteed.

\section{RESULTS}

The caregivers' average age was 35.7 years $(S D=8.7)$, with a range from 15 to 74 years. Time spent providing care for children was between 0 and 24 hours $(\overline{\mathrm{X}}=5.20, s=$ 3.67). The largest proportion of respondents were mothers (87.4\%), of whom $74.8 \%$ reported having a partner, while the rest were single, widowed, separated, or divorced. A total of $63.1 \%$ of the women were homemakers, followed by service providers $(27.4 \%)$, and the remainder $(9.5 \%)$ were engaged in other occupations or unemployed (Table 1).

The primary characteristics of the children referred by the caregivers in the study were: $60 \%$ female; $70.2 \%$ were nine years old or older $(\overline{\mathrm{X}}=11.09, s=3.46)$; most attended elementary school $(57.1 \%)$; and $46.1 \%$ were the first born child in the family (Table 2).

Construct validity and internal consistency for the Parental Practices Inventory (PPI). The item concerning privileges was removed because it failed to discriminate $(t[231]=-.709, p=.479)$. The original exploratory factor analysis for the scale included 36 items resulting in nine components that explained $43.7 \%$ of the total variance with $\alpha=.882$. However, since five of the nine components com- 
Table 3

Factorial analysis of elements $N=442$

\begin{tabular}{|c|c|c|c|}
\hline $\begin{array}{l}\text { Sample adequacy measure } K M O^{1}=.89 \\
\text { Global scale } \alpha=.867 \text { Explained variance }=41.257\end{array}$ & $\begin{array}{l}\text { Factor } \\
\text { load }\end{array}$ & $\begin{array}{l}\text { Explained } \\
\text { variance }\end{array}$ & $\begin{array}{l}\text { Cronbach's } \\
\text { Alpha }\end{array}$ \\
\hline FCDP Firm, consistent discipline practices Subscale & & $3.94 \%$ & .75 \\
\hline 1. When I ask my child to do something, I go straight to the point and my request is clear. & .470 & & \\
\hline $\begin{array}{l}\text { 2. Throughout the day, I try to notice when my child is behaving well and I show my child that I } \\
\text { like their behaviour. }\end{array}$ & .480 & & \\
\hline 24. Those of us sharing the duty of caring for this child agree on how to handle their behaviour. & .565 & & \\
\hline 34. My child and I talk to discuss problems and decision making. & .463 & & \\
\hline $\begin{array}{l}\text { 36. When my child asks questions I answer, showing interest and enthusiasm and I do not feel } \\
\text { irritated. }\end{array}$ & .495 & & \\
\hline 37.I am firm and consistent in how I discipline my child. & .554 & & \\
\hline IP Involvement Practices Subscale & & $23.18 \%$ & .83 \\
\hline 3. My child and I watch television together. & .544 & & \\
\hline $\begin{array}{l}\text { 8. When my child and I make plans to do something fun together, what we end up doing is actu- } \\
\text { ally fun. }\end{array}$ & .585 & & \\
\hline 13.I use phrases like, "thank you" "carry on" to praise my child. & .615 & & \\
\hline 16.I do fun things with my child. & .743 & & \\
\hline 19. My child and I do chores together and we both enjoy it. & .539 & & \\
\hline 21. I spend time with my child talking or playing without telling them what to do or ordering them about. & .401 & & \\
\hline $27 . I$ sing and dance with my child. & .585 & & \\
\hline 31.I play with my child (e.g., board games, hide-and-seek, sports, playing house, etc.). & .603 & & \\
\hline NIP Inadequate and Negligent Practices Subscale & & $11.13 \%$ & .80 \\
\hline 4. When my child does not do as I ask, I end up doing it myself. & .644 & & \\
\hline 10.I have to insist in order for my child to do what I asked them to do. & .618 & & \\
\hline 12. When my child does something bad or that I do not like, I insult him or her. & .568 & & \\
\hline 17.I yell at my child when he or she misbehaves. & .563 & & \\
\hline 20. When my child does not do as I ask, we end up arguing. & .749 & & \\
\hline 23. Arguments with my child are interminable. & .463 & & \\
\hline PC Coercive Practices Subscale & & $3.00 \%$ & .67 \\
\hline $\begin{array}{l}\text { 9. When my child does something bad or that I do not like, I send him or her to a room and make } \\
\text { him or her stay there alone. }\end{array}$ & .566 & & \\
\hline 15. When my child does something bad that I do not like, I hit or slap him or her. & .600 & & \\
\hline 29.I threaten to go or leave my child alone if he or she does not behave better. & .473 & & \\
\hline 33. When my child does something bad or that I do not like, I hit him or her with a belt or another object. & .496 & & \\
\hline
\end{tabular}

Notes: Maximum likelihood extraction method with Kaiser varimax rotation; $\mathrm{KMO}^{1}=$ Kaiser-Meyer-Olkin.

prised two items, a second analysis was done using a criterion of four components, based on Salas' (2001) analysis of the revised PPI, with a $41.25 \%$ explained variance. Only twenty-four items were validated in this analysis $(\alpha=.867)$, since items related to the following were excluded: threats, rewards, storytelling, underestimating, explaining, co-management of behaviour, shared experiences, manipulation, withholding privileges, anger, lack of self-control, and the child's lack of self-control. Each of the four subscales were labelled by the type of questions: 1 . involvement practices (IP, $\alpha=.83$ ); 2. firm, consistent discipline practices (FCDP, $\alpha=.75$ ); 3. negligent, inadequate practices (NIP, $\alpha=.80$ ); and 4 . coercive practices (CoP, $\alpha=.67)$ (Table 3 ).

Validity of Parenting Practices Inventory (PPI) through confirmatory factorial analysis. A confirmatory factor analysis was conducted with the results obtained from the exploratory factor analysis of the four areas under consideration. Using the Lagrange multipliers, a good fit for the model was obtained (Figure 1), based on the correlation between the errors pertaining to the same factor. The statistics found were $\mathrm{X}^{2}{ }_{\mathrm{SB}}=356.5130(d f=235$, $p=.000), \mathrm{RMSEA}=.034$ with CI90\% ${ }_{\mathrm{RMSEA}}=.027-.041$, $\mathrm{RCFI}=.950$. Since the value of $\mathrm{X}^{2}$ for the four-component model was significant $(p=.000)$, and since we had a large sample, we calculated the adjustment indicator through $\mathrm{X}^{2} / \mathrm{df}=1.52$.

Parenting practices and sociodemographic variables. The means presented for each subscale were: IP $(\bar{X}=11.68$, $\mathrm{SD}=4.85), \operatorname{FCDP}(\overline{\mathrm{X}}=8.39, \mathrm{SD}=4.03), \operatorname{NIP}(\overline{\mathrm{X}}=4.51$, $\mathrm{SD}=3.58)$, and $\operatorname{CoP}(\overline{\mathrm{X}}=1.35, \mathrm{SD}=1.69)$. 


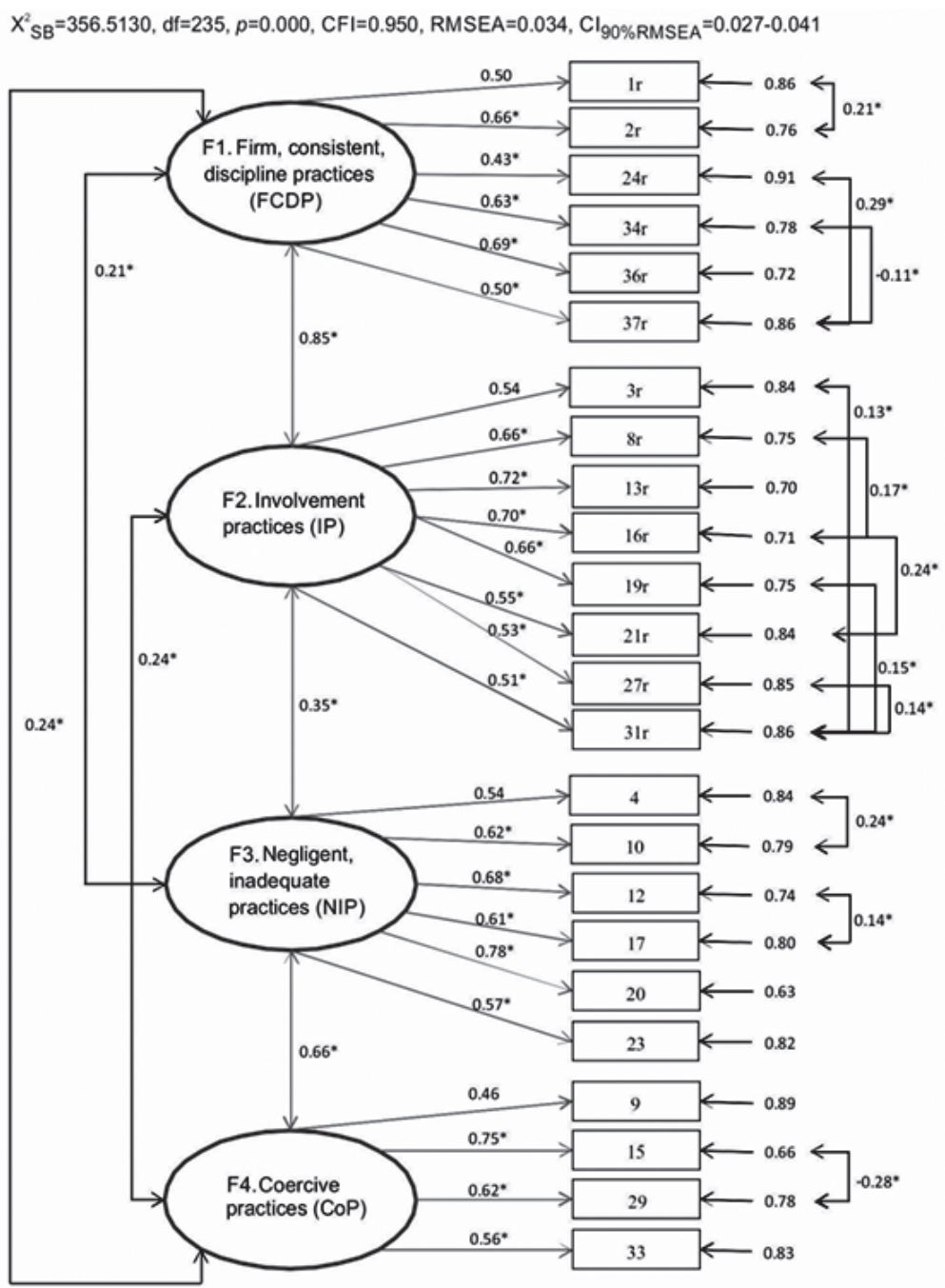

Figure 1. Model of confirmatory factor analysis for the parenting practices inventory $(N=442)$.

The results by caregiver occupation show that homemakers use more NIP $(\overline{\mathrm{X}}=4.82, S D=3.56)$ than other occupations $(\overline{\mathrm{X}}=4.10, S D=3.62) t(410)=1.97, p=.049$. Similar results were observed for $\mathrm{CoP}$ among homemakers $(\overline{\mathrm{X}}=1.49, S D=1.80)$ in comparison with other occupations $(\overline{\mathrm{X}}=1.15, S D=1.51) t(360.72)=2.078, p=.038)$.

A comparison of the parenting practices used by caregivers according to the child's age groups: 5 to 8 years, 9 to 12 years, and 13 years or over showed significant differences in the use of CoPs $(\mathrm{F}[2]=8.43, p<.001)$. Using the Bonferroni post hoc test, a higher rate of CoPs in children aged 5 to 8 years old $(\overline{\mathrm{X}}=1.72, S D=1.87)$ and a low rate in the elder group $(\overline{\mathrm{X}}=.94, S D=1.42)$ were identified. Also, differences were observed for the IP (F [2] $=3.166, p=.043)$, with a lower average for children aged 5 to 8 years old $(\bar{X}=10.81$, $S D=4.95)$, when compared to the other two group $(\overline{\mathrm{X}}=12.20$, $S D=4.71 ; 9$ to $12: \overline{\mathrm{X}}=11.90, S D=4.84)$.

\section{DISCUSSION AND CONCLUSION}

The aim of the study was completely accomplished. Research instruments as evaluation tools for various issues require an estimation of their internal consistency and construct validity for the specific population being studied, since having valid, reliable instruments for the research groups may contribute to the progress of scientific knowledge in different areas. Roncero (2015) demonstrated that there is a need to further study various issues and to validate the use of research tools in populations sharing the same language. In this respect, research on parenting practices becomes more relevant and meaningful in the area of public health, because of their repercussions on children's physical and psychological health.

The PPI instrument showed an appropriate internal consistency index $(\alpha=.867)$, similar $(\alpha=.850)$ to that reported by Bauermeister et al. (2005). This indicates that the 
instrument has sufficient consistency and stability to be applied to other populations.

Construct validity was adequate, since it evaluated what it was seeking to measure (Aguirre, 2014). Both the relevance and the representativeness of its content and its relation to the PPI criteria were confirmed. The 24 items comprised four subscales, which together explain $41.2 \%$ of the total variance. Confirmatory analysis showed the model's good fit with the structure of four factors grouped into two central elements called positive and negative parenting, with a CFI $=.950$ being considered the most admissible (Messick, 1995; Jackson, Gillaspy, \& Purc-Stephenson, 2009).

Due to the characteristics of the population of this study, items removed from the original version of the PPI were related to the affirmation of power and the use of force for behaviour regulation and control, storytelling, underestimating, explaining, co-management of behaviour, sharing experiences, lack of self-control, and the child's lack of self-control. This aspect could be explained by the affirmation Covarrubias and Gómez (2012) made regarding the changes or resignifications of the Mexican families in their current practices (e.g., demanding with flexibility and authority, physical punishment without reaching levels of physical or verbal abuse, providing affection, and intentionally avoiding the mistakes made in their families of origin).

The strengths observed during this study are evidence of the confirmatory construct validity of the PPI in a representative group of caregivers seeking care at a Mexico City health centre. Furthermore, it was coherent with the theoretical evidence and the organization of the PPI. Both reliability and structure were consistent with Salas' (2001) adaptation of the PPI. This suggests that the instrument's psychometric function is adequate and that it provides relative confidence about the interpretation and scope of the results.

The results also showed that consistent, firm discipline practices are highly correlated with involvement practices, whereas negligent, inadequate practices are associated with coercive practices, thus resembling results from other authors (Aguirre, 2014; Cabrera, González, \& Guevara, 2012; Vite Sierra \& Pérez Vega, 2014), using different instruments and in other populations.

Interestingly, homemakers (who were predominant among the respondents) tended to use more coercive and negligent practices. Moreover, coercive practices were reported in higher numbers for younger children, as well as a lower number of involvement practices. As involvement practices explained most of the variance, the results suggest that preventive efforts should be directed on this topic (Soriano, García, \& Caraveo, 2016).

There are limitations related to the nature of the study undertaken. The results only represent the type of population interviewed and cannot be extrapolated to the general population. There is therefore a need to continue to research the topic, using larger participant samples and providing more evidence on the way the inventory functions. However, this design showed adequate functioning. Likewise, future research should determine the possible link between the parenting practices of the primary caregiver and the presence of mental symptomatology in children and adolescents.

Results derived from the consistency and validity analyses provided substantial psychometric evidence to support the usefulness of the PPI in its current, 24-item version as a potential tool for researching parenting practices used by the caregivers of children and adolescents aged 5 to 19 in Mexico City. It made it possible to find differences in the type of practices used, either by the children's age groups or the type of caregiver, as has been found in other reports of the literature.

Lastly, findings of this study have major implications for the development of programmes in a variety of contexts, where parenting practices are important for children's physical and psychological health. They also reflect a resignification of parenting practices in Mexico, which points to the need to reevaluate the relationship between parenting beliefs and practices.

\section{Funding}

This study was funded by CONACYT: Salud-2003-C01-60.

\section{Conflict of interests}

The authors declare that they have no conflict of interests.

\section{Acknowledgements}

We would like to thank the authorities at the Secretaría de Salud in Mexico City for their support in the completion of this study; the professionals who participated; and the respondents for their time and support in undertaking this study. We are also grateful to CONACYT for funding the project: Epidemiological Mental Health Watch for Children and Adolescents.

\section{REFERENCES}

Aguirre,A. (2014). Validez del inventario de practicas de crianza (CPC-1 versión padres) en padres madres y cuidadores de la ciudad de Bogota. Revista Iberoamericana de Psicología: Ciencia y Tecnología, 7(1), 79-90. Retrieved from: http://revistas. iberoamericana.edu.co/index.php/ripsicologia/article/view/484

Arnold, D. S., O'leary, S. G., Wolff, L. S., \& Acker, M. M. (1993). The Parenting Scale: A measure of dysfunctional parenting in discipline situations. Psychological assessment, 5(2), 137-144. doi: 10.1037/1040-3590.5.2.137

Bauermeister, J., Cumba, E., Martínez, J., \& Puente, A. (2008). El Inventario de Experiencia Familiar: Una medida del impacto de los hijos e hijas en los padres y madres. Revista Puertorriqueña de Psicología, 19, 216-222. Retrieved from: http://www.redalyc.org/articulo.oa?id=233216360009

Bauermeister, J., Matos, M., Reina, G., Salas, C., Martínez, J., Cumba, E., \& Barkley, R. (2005). Comparison of the DSM-IV combined and inattentive types of ADHD in a school-based sample of Latino/Hispanic children. Journal of Child Psychology and Psychiatry and Allied Disciplines, 46(2), 166-179. doi. org/10.1111/j.1469-7610.2004.00343.x

Bentler, P. \& Wu, E. (2005). EQS 6 for Windows guide. Encino, CA: Multivariate Software.

Cabrera, V., González, M., \& Guevara, I. (2012). Estrés parental, trato rudo y monitoreo como factores asociados a la conducta agresiva. Univ Psychol, 11(1), 241-254. doi: 10.11144/Javeriana.upsy11-1.eptr 
Caraveo-Anduaga, J. J., López-Jiménez, J. L., Soriano-Rodríguez, A., LópezHernández, J. C., Contreras-Garza, A., \& Reyes-Mejía, A. (2011). Eficiencia y validez concurrente del CBTD para la vigilancia de la salud mental de niños y adolescentes en un centro de atención primaria de México. Revista de Investigación Clínica, 63(6), 590-600.

Caraveo-Anduaga, J. J. (2016). Vigilando la salud mental infantil en atención primaria. Norderstedt, Germany: Editorial Académica Española. p 142. ISBN 978-3-639-82727-9

Covarrubias, A. \& Gómez, J. (2012). Transformación y contemporaneidad de la familia: el caso de las familias mexicanas. Rev Psicol, 14(2), 244-259. Retrieved from: http://sisbib.unmsm.edu.pe/BVRevistas/rev_psicologia_cv/v14_2012_2/ pdf/a09v14n2.pdf

Cuervo, A. (2010). Pautas de crianza y desarrollo socioafectivo en la infancia. Diversitas: Perspect Psicol, 6(1), 111-121. doi: 10.15332/s17949998.2010.0001.08

Darling, N. \& Steinberg, L. (1993). Parenting style as context: An integrative model. Psychological Bulletin, 113(3), 487-496. doi: 10.1037/0033-2909.113.3.487

Denham, S., Workman, E., Cole, P., Weissbrod, C., Kendziora, K., \& ZahnWaxler, C. (2000). Prediction of externalizing behavior problems from early to middle childhood: The role of parental socialization and emotion expression. Development and Psychopathology, 12(1), 23-45. doi: 10.1017/ S0954579400001024

Forgatch, M. \& Patterson, G. (2010). Parent Management Training - Oregon Model: An intervention for antisocial behavior in children and adolescents. In: Weisz J, Kazdin A, (Eds). Evidence-Based Psychotherapies for Children and Adolescents. Second Edition. New York, NY: Guilford Press. p 159-178. Retrieved from: https://www.researchgate.net/publication/285033077_Parent_ management_training-Oregon_model_An_intervention_for_antisocial_ behavior_in_children_and_adolescents/download

Forgatch, M., Patterson, G., Degarmo, D., \& Beldavs, Z. (2009). Testing the Oregon delinquency model with 9-year follow-up of the Oregon Divorce Study. Development and Psychopathology, 21(2), 637-660. doi: 10.1017/ S0954579409000340

Hill, J. (2002). Biological, psychological and social processes in the conduct disorders. Journal of Child Psychology and Psychiatry and Allied Disciplines, 43(1):133-164. doi: 10.1111/1469-7610.00007

IBM. (2012). Manual del usuario del sistema básico de IBM SPSS Statistics 21. Retrieved from: ftp://public.dhe.ibm.com/software/analytics/spss/ documentation/statistics/21.0/es/client/Manuals/IBM_SPSS_Statistics_Core_ System_Users_Guide.pdf

Jackson, D. L., Gillaspy, A., \& Purc-Stephenson, R. (2009). Reporting practices in confirmatory factor analysis: An overview and some recommendations. Psychological Methods, 14(1): 6-23. doi: 10.1037/a0014694, Retrieved from: https://pdfs.semanticscholar.org/1b35/5f17ff8ae7ac103fe0f2177f5937129a5 0c4.pdf

Kerlinger, F. N. (1986). Foundations of Behavioral Research. (Third edition) New York: Holt, Rinehart and Winston.

Kerlinger, F. N. \& Lee, H. . (2002). Investigación del comportamiento. MC Graw Hill.

Lloret-Segura, S., Ferreres-Traver, A., Hernández-Baeza, A., \& Tomás-Marco, I. (2014). Exploratory item factor analysis: A practical guide revised and updated. Anales de Psicología, 30(3), 1151-1169. doi: 10.6018/analesps.30.3.199361
Messick, S. (1995). Validity of psychological assessment: Validation of inferences from persons' responses and performances as scientific inquiry into score meaning. American Psychologist, 50(9), 741-749. doi.org/10.1037//0003066X.50.9.741

Myers, R. (1993). Los doce que sobreviven: fortalecimiento de los programas de desarrollo para la primera infancia en el tercer Mundo. Washington, D.C.: Organización Panamericana de la Salud. doi: 10.1590/S003646651994000200020

Pichardo, C., Justicia, F., \& Fernández, M. (2009). Prácticas de crianza y competencia social en niños de 3 a 5 años. Pensamiento Psicológico, 6(13), 37-48.

Ramírez, M. (2007). Los padres y los hijos: variables de riesgo [Parents and children: risk variables]. Educación y Educadores, 10(1), 27-37.

Repetti, R., Taylor, S., \& Seeman, T. (2002). Risky families: Family social environments and the mental and physical health of offspring. Psychological Bulletin, 128(2), 330-366. doi: 10.1037//0033-2909.128.2.330

Roncero, C. (2015). La validación de instrumentos psicométricos: Un asunto capital en la salud mental. Salud Mental, 38(4), 235-236. doi: 10.17711/SM.01853325.2015 .032

Salas, C. (2001). La crianza de los ninos y las ninas con el trastorno por deficit de atencion e hiperactividad y su entorno familiar y social. ProQuest Dissertations and Theses Global. Retrieved from: http://search.proquest.com/docview/30474 0097? accountid $=44825$

Séguin, J. \& Pilon, M. (2013). Conduct and oppositional defiant disorders. In: Reddy, L., Weissman, A., \& Hale, J. (Editors). Neuropsychological assessment and intervention for youth: An evidence-based approach to emotional and behavioral disorders. Washington, DC, US: American Psychological Association. p 177200. doi: 10.1037/14091-008

Shaw, D., Gilliom, M., Ingoldsby, E., \& Nagin, D. (2003). Trajectories leading to school-age conduct problems. Developmental Psychology, 39(2), 189-200. doi: 10.1037/0012-1649.39.2.189

Solís-Cámara, P. \& Díaz, M. (2007). Relaciones entre creencias y prácticas de crianza de padres con niños pequeños. Anales de Psycología, 23( 2), 177-184.

Soriano, A., Garcia, F., \& Caraveo, J. (2016). Guía para orientar el manejo parental de la conducta de niños y adolescentes en la práctica clínica. In: Vigilando la Salud Mental Infantil en Atención Primaria. Guías prácticas para profesionales e investigadores de la salud. Saabrücken, Deutschland: Editorial Académica Española. p 148.

Strayhorn, J. M. \& Weidman, C. S. (1988). A parent practices scale and its relation to parent and child mental health. Journal of the American Academy of Child \& Adolescent Psychiatry, 27(5), 613-618. doi: 10.1097/00004583-19880900000016

Vera, E. \& Moon, B. (2013). An Empirical Test of Low Self-Control Theory: Among Hispanic Youth. Youth Violence and Juvenile Justice, 11(1), 79-93. doi: $10.1177 / 1541204012441628$

Vite Sierra, A. \& Pérez Vega, G. (2014). El papel de los esquemas cognitivos y estilos de parentales en la relación entre prácticas de crianza y problemas de comportamiento infantil. Avances en Psicologia Latinoamericana, 32(3), 389402. doi: 10.12804/ap132.03.2014.04 